\title{
Cyborg Spirituality
}

\author{
ANDREW PICKERING*
}

\begin{abstract}
Keywords: Psychiatry; Antipsychiatry; Double Bind; Brain; Performance; Adaptation; Spirituality; Eastern Philosophy; Cybernetics; Ontology
\end{abstract}

This article explores crossovers from Eastern philosophy and spirituality to contemporary science and medicine in the West. My interest is not so much in specific lines of historical transmission, as in the channels through which they flow. In particular, my argument is that different ontologies - visions of how the world is - either facilitate or block such exchanges. As an example, think about physics. The ontology of mainstream physics is a modern, dualist one, inasmuch as physical thought revolves around a material world from which anything human is absent, and the human leftovers fall to the humanities and social sciences. This ontology, more or less by definition, blocks any resonance with Eastern ideas or practices, and, accordingly, they are almost entirely absent from the history of physics, except, importantly, in lines of work on the foundations of physics, especially quantum mechanics. If one meditates on the Heisenberg uncertainty principle, for instance, boundaries between the observer and the observed start to unravel, the dualist ontology erodes, and there, indeed, one finds all sorts of resonances with the East, as elaborated in an endless list of books that includes, for example, The Tao of Physics and The Dancing Wu Li Masters. ${ }^{1}$ That is my basic idea: resonances with the East spring forth in Western science whenever modern dualism starts to fray around the edges. But this essay is not about physics, and I turn now to the post-war history of cybernetics in Britain and its rather different non-modern ontology. ${ }^{2}$

(C) Andrew Pickering, 2011.

* Andrew Pickering, Professor of Sociology and Philosophy at Exeter University and Professor of Sociology at Kyung Hee University in Seoul, Korea, , Address: Department of Sociology and Philosophy, University of Exeter, Amory Building, Rennes Drive, Exeter EX4 4RJ, UK.

Email: a.r.pickering@exeter.ac.uk

\footnotetext{
${ }^{1}$ Fritjof Capra, The Tao of Physics: An Exploration of the Parallels between Modern Physics and Eastern Mysticism (London: Fontana, 1976), Gary Zukav, The Dancing Wu Li Masters: An Overview of the New Physics (London: Fontana, 1980). David Bohm's non-standard approach to quantum mechanics often figures prominently in this connection; see Orlando Fernandez, 'Esotericism and
}

the Interpretation of Quantum Mechanics: David Bohm (1917-1992),' paper presented at the 20th IAHR World Congress, Toronto, 15-21 August 2010. More recently than quantum mechanics, the sciences of complexity also undercut modern dualisms, and there too one finds connections to the East. See, for example, Fritjof Capra, The Web of Life: A New Scientific Understanding of Living Systems (New York: Anchor Books, 1996) and Ralph Abraham, Terence McKenna and Rupert Sheldrake, Trialogues at the Edge of the West: Chaos, Creativity and the Resacralization of the World (Santa Fe, NM: Bear \& Co., 1992).

${ }^{2}$ Full documentation of what follows is to be found in Andrew Pickering, The Cybernetic Brain: Sketches of Another Future (Chicago: University of Chicago Press, 2010). 


\section{Andrew Pickering}

Cybernetics is usually thought of as a worldly science, originally focused on the brain but opening out into robotics, psychiatry, complexity, management, the arts and so on. But when one looks more closely, one continually stumbles across veins of strange and unorthodox spirituality, often, though not always, Eastern ones. Grey Walter was one of the founders of cybernetics in Britain and his 1953 popular book, The Living Brain, is, on the one hand, a down-to-earth, materialist and evolutionary story of how the brain functions, ${ }^{3}$ but it is also full of references to dreams, visions, ESP, nirvana and the magical powers of Eastern yogis such as suspending the breath and the heartbeat. In his private journal, Ross Ashby, the other great first-generation British cybernetician, announced that intellectual honesty required him to be a spiritualist, that he despised the Christian image of God, and that instead he had become a 'Time worshipper' ${ }^{4}$ In the second generation, Gordon Pask wrote supernatural detective stories, while Stafford Beer was deeply absorbed by mystical number systems and geometries, happily sketching out his version of the great chain of being, teaching tantric yoga and attributing magical powers such as levitation to his fictional alter ego, the Wizard Prang.

How can we make sense of this outbreak of esotericism in recent science? We should start with the brain, the original referent of cybernetics. Since the Western Enlightenment, our standard understanding has been of the brain as the organ of reason and cognition - a strongly dualist image, in which reason is precisely what distinguishes us from animals and things and elevates us above them. ${ }^{5}$ But, as Ashby put it in 1948, from a cybernetic perspective, 'the brain is not a thinking machine, it is an acting machine; it gets information and then it does something about it. ${ }^{6}$ The cybernetic brain was, so to speak, performative rather than cognitive, immediately engaged in bodily performance and goings-on in the world; and here we can note that this performative perspective on the brain directly subverts Cartesian dualism: if thinking is what distinguishes us from animals and things, performance is instead what we have in common with them; and, in turn, this ontological shift is what set up cybernetics' openings to the East.

First, while we seem to have immediate access to our cognitive processes - I know how I do sudoku puzzles - we have no equivalent access to the performative brain at pre- or noncognitive levels of being. So a specific avenue of exploration opens up here: who knows what a performative brain can do? In cybernetics, this question translated into an intense interest in what I call altered states and strange performances. Some of these were mundane: epilepsy, madness. Others were artificially induced: the strange and beautiful visions evoked by staring into a flickering strobe light. But Eastern traditions were also taken up as a source of information, and this is how yogic powers and so on found their way into Walter's book - precisely as interesting examples of what a performative brain can do. This is one way in which the non-dualist emphasis on performance made the link to the East.

From another angle, the cybernetic brain was not just performative but adaptive, understood as the organ that helps us get along in a world that can always surprise us. The model for this was a machine called the homeostat that Ashby built in 1948, which

\footnotetext{
${ }^{3}$ W. Grey Walter, The Living Brain (London: Duckworth, 1953).

${ }^{4}$ Pickering, op. cit. (note 2), 111.

${ }^{5}$ Andrew Pickering, 'Against Human

Exceptionalism,' paper presented at a workshop on
} 


\section{Cyborg Spirituality}

randomly reconfigured itself in the attempt to come into dynamic equilibrium with its environment, which was in turn modelled by more homeostats. Modelling the brain and the environment with identical machines, of course, further subverted Cartesian dualism, staging a vision of the brain and the world as structurally isomorphous, and again provided an opening to the East. And if the cognitive brain can be understood as a stable centre of will, calculation and planning, the notion of adaptation spoke instead of a brain and self intimately caught up in the thick of things, continually reconfigured in a decentred dance of agency - which is, more or less, the Buddhist analysis of the self. At the limit, both Walter and Ashby spoke of dynamic equilibrium as a state of nirvana - a sort of calm detachment from worldly inputs.

So we can see that in cybernetics, as in physics, a non-dualist ontology, now centred on the performative brain, provided the channel through which Eastern philosophy and spirituality could run into Western science. In cybernetics, the East offered a set of fascinating examples of altered states and strange performances, and important concepts for thinking about decentred selves and adaptive states of equilibrium.

Rather than going further at this level of generality, we can turn to a more detailed example. In the 1950s, another British founder of cybernetics, Gregory Bateson, became interested in communication patterns in the families of schizophrenics, resulting in his famous concept of the double bind. On the model of interacting homeostats, Bateson understood the double bind as the achievement of some unfortunate form of adaptive equilibrium, in which one or more of the participants gets stuck in a painful oscillation between states and can find no normal way to go on. Schizophrenia, on this account, is a desperate and unconventional attempt to escape the double bind at some higher level of adaptation. Interestingly, in the present context, Bateson drew upon Zen Buddhism to fill out the picture, comparing the double bind situation to the paradoxical instructions given by the Zen master to his disciple: 'if you say this stick is real, I will strike you with it; if you say this stick is not real, I will strike you with it. If you don't say anything, I will strike you with it' - a sort of performative koan. ${ }^{7}$ In both instances, an impossible situation leads to a dissolution of the modern self, though the upshots are different: respectively madness and Eastern enlightenment. Bateson thus drew on the Buddhist tradition to understand madness as not simply a pathological departure from normality but as also containing elements of transcendence - locating the mundane modern self not as the paradigm of dualist humanity but in the middle of a non-modern performative spectrum running from madness via normality to ecstasy, from Heaven to Hell.

Here we can make a concrete historical connection to the East. Members of Bateson's group had taken courses at the American Academy of Asian Studies in San Francisco with Alan Watts - another expatriate Englishman, and one of the great early popularisers of Zen in the West. Watts was himself a consultant to Bateson's group, and he returned the compliment by drawing upon cybernetics to explain Buddhist concepts in his 1957 book, The Way of Zen - a rare example of the reverse flow from Western science into Eastern philosophy. ${ }^{8}$

${ }^{7}$ Ibid., 175.

${ }^{8}$ Alan Wilson Watts, The Way of Zen (New York: Pantheon, 1957). 


\section{Andrew Pickering}

Bateson's other great contribution to psychiatry was his concept of psychosis as an 'inner voyage', spelled out in the book he edited in 1961, Perceval's Narrative. ${ }^{9}$ This voyage Bateson understood as an adaptive process of 'discovery' in the world of inner experience, from which the sufferer 'comes back with insights different from those... who never embarked on such a voyage. ${ }^{10}$ Bateson compared the voyage to an initiation ceremony and a process of death and rebirth - a dissolution and reconstitution of the self. Bateson himself did not elaborate to any extent on the phenomenology of the inner voyage, but to get at that we can turn to another English exile to California, Aldous Huxley. His 1954 book, The Doors of Perception, is a brilliant essay that takes off from his experiences on first taking mescaline. Huxley describes this experience in specifically non-dualist terms, speaking, for example, of becoming the leg of a chair he was contemplating. He also invokes Eastern philosophy as a vehicle for conveying the intensity of his mescaline experience, describing his ecstatic vision as glimpsing 'the dharma body of the Buddha in the hedge at the bottom of the garden'. Huxley, like Bateson, saw madness and transcendence as being in the same space - with the schizophrenic involuntarily trapped in the unbearable wonder of enlightened perception. ${ }^{11}$

These elements - the analysis of the double bind; the idea of psychosis as an inner voyage; a Buddhist account of the self, of the workings of the double bind, and of the phenomenology of the trip - were central to the anti-psychiatry movement in Britain in the 1960s, and came down to earth at a place called Kingsley Hall in London in 1965. Established by R.D. Laing and his colleagues in the Philadelphia Association, Kingsley Hall was a commune in which psychiatrists and sufferers lived together on a par, with the former trying to help the latter in their inner voyages in any way they could, while expecting themselves to be reciprocally transformed in the process. Laing's analysis was that in modernity we are all profoundly mad, precisely in our disconnection from the world of inner experience, and he looked to both Eastern and Western mystical traditions for inspiration in making some sort of reconnection.

Kingsley Hall itself closed down in 1970, and Laing went to Sri Lanka for a year to meditate. The experiment continued throughout the 1970s in a series of condemned houses in Archway, north London, and in the Archway communities the Eastern influence became even stronger. One of the therapists, Leon Redler, invited Zen masters to stay at his flat and, importantly, encouraged the residents to take up all sorts of Eastern practices, including hatha yoga, meditation, aikido, tae-kwon-do, massage, and a diet of rice, beans and vegetables. Herbalists and acupuncturists also cared for the sufferers. The non-dualist upshot of this, according to David Burns, one of the residents, was that:

We realized the importance of the body, of the body-mind continuum... Much of what is called 'mental illness' is actually physical suffering, whether it be skin rashes, insomnia, vomiting, constipation, or general anxiety-tension. The schizophrenic process is endurable and can be meaningful in a context of minimal physical stress. ${ }^{12}$

\footnotetext{
${ }^{9}$ Gregory Bateson (ed.), Perceval's Narrative: A Patient's Account of His Psychosis, 1830-1832 (Stanford, CA: Stanford University Press, 1961).

${ }^{10}$ Pickering, op. cit. (note 2), 178.
}

\footnotetext{
${ }^{11}$ Aldous Huxley, The Doors of Perception, and Heaven and Hell (New York: Harper \& Row, 1963).

${ }^{12}$ Pickering, op. cit. (note 2), 197-8.
} 


\section{Cyborg Spirituality}

In Archway, then, Eastern traditions figured not just as an interpretive resource for grasping altered states and strange performances, but as a source of technologies of the non-modern and non-dualist self. ${ }^{13}$

That is as far as I can take this story. The connection between non-dualist ontologies in science and medicine and Eastern philosophy and spirituality is obvious once one has seen it, but it is nevertheless interesting and illuminating to see how it plays out in specific cases: here in the history of cybernetics and psychiatry, establishing a continuum in which the sacred and the profane became more or less the same thing. The final question might be: what has happened to this non-modern East-West cybernetic assemblage we have been examining? It has been largely forgotten, or walled off behind the label of New Age as something one does not talk about in polite society. Now we live in the world of Prozac and reductive brain chemistry. We academics might be able to think our way past Cartesian ontology but, in the real world, dualism, like capitalism, has turned more vicious since the 1960s. No one hitchhikes to India anymore, and the ontological route has been shut down too.

\section{Acknowledgements}

This work was supported by a National Research Foundation of Korea grant funded by the Korean Government (NRF-2010-330-B00169). This paper was revised for publication while I was a Distinguished Fellow at the Institute of Advanced Study and Pemberton Fellow at University College, Durham, and I thank the Institute and College for their generous support.

\footnotetext{
${ }^{13}$ M. Foucault, Technologies of the Self: A Seminar with Michel Foucault (Amherst, MA: University of Massachusetts Press, 1988).
} 